\title{
THE INSTITUTION OF ACCOUNTING NORMALISATION IN ROMANIA - HISTORY AND PRESENT
}

\author{
Aristiţa Rotilă \\ "Vasile Alecsandri" University of Bacău \\ rotila11@yahoo.com
}

\begin{abstract}
The institution of accounting normalization at a national level can essentially be as public, private and mixed. On its nature depend the way of accepting/imposing the accounting norms and also the character of these norms, character which can be more or less restrictive. The present article is a study regarding the institution of normalization of accounting in Romania from the beginning (when the process of normalizing the Romanian accounting began) to present, following its changes through two stages which have marked the evolution of our country in the second half of the $20^{\text {th }}$ century and beginning of the $21^{\text {st }}$ century: the stage of socialism, having a centralized economy, and the stage of transition to a market economy, which started right after the 1989 Revolution. Within post-revolutionary stage, under the Ministry of Finances, the institution of accounting normalization in Romania, a mixed organism was created, which sums up a large series of "actors" interested in the accounting information and has the role of allowing those actors to involve into the process of normalization, which would let the Romanian accounting normalization pass from an exclusively public approach to a mixed one.
\end{abstract}

Keywords

accounting; institution; normalization; norms; Ministry of Public Finances

\section{JEL Classification}

M41

\section{Introduction}

It is known that accounting information should be accessible to a large number of users. To meet their needs, the production of accounting information, the disclosure of the financial statements and its publication must be made according to certain rules and regulations through the implementation of which information that meet certain qualitative characteristics, should be obtained. Therefore, it arises the need for accounting normalization. To achieve the objectives of the normalization of accounting, development and improvement of accounting, is necessary a credible institution of accounting normalization (Ristea, 2009).

The national institution of the normalization of accounting can essentially be public (of the state), private (of the accounting profession) or mixed.

Taking into account the possibility of the acceptance of accounting norms by the affected parties, dependent on the nature of the institution normalizing and the balance of forces in the conflicts of interest, ie the ratio of public and private contribution, acceptance being forced or voluntary, or both at the same time, one can speak of two major forms of normalization, the resulting combination of them and a third form, mixed, ie (Rotilă, 2011): the legal normalization or the regulated approach called political or public; the professional normalization, called pragmatic approach, and the normalization of mixed type (Feleagă \& Ionaşcu, 1998), achieved through cooperation between the public and private factors. 
The normalization of accounting in Romania, an exclusively public normalization, started in the first year of planned management of the national economy, 1949, its evolution being marked by the economic, social and political Romanian society and also by the global developments. It is considered that the process of normalization of accounting in our country started with the development and implementation in 1949 of the chart of accounts for industrial enterprises, approved by the Resolution of the Council of Ministers no. 1636 from $10^{\text {th }}$ December 1948, although previously there had been some concerns on this issue, which were reflected in the university courses and in scientific communications of specialists.

We are going to present the evolution of institution of accounting normalization in Romania from the beginning (when the process of normalizing the Romanian accounting began) to present, structured on two stages which have marked the evolution of our country in the second half of the $20^{\text {th }}$ century and beginning of the $21^{\text {st }}$ century: the stage of socialism (since 1949), having a centralized economy, ruled by the one and only central national plan, and the stage of transition to a market economy, which started right after the 1989 Revolution. The end of the $20^{\text {th }}$ century represents for the Romanian system of accounting a fresh start, entering a new stage of development and perfectionism tightly connected to the trends manifested in Europe and also, worldwide.

\section{Bodies involved in Romanian accounting normalization in the period of centralized economy (1949-1989)}

During the planned economy, the normalizing of accounting was exclusively the privilege of the state, represented by the Ministry of Finances, inside of which a specialized direction was created.

The organism charged with normalizing the accounting was, thus, the Direction of Norming of Accounting Evidence (Direcţia normării evidenţei contabile), founded by the decision of the Council of Ministers no. 1636 from December, 10 $0^{\text {th }}$ 1948, concerning the compulsory introduction of normed accounting. Prior to this organism had been, since 1947, the Permanent Council for the Norming of the Industrial and Commercial Accounting, set as part of the Ministry of the Industry and Commerce.

In time, the name of this Direction changed as following: the Direction of Norming and Guiding of Accounting (Decree no. 30/1949), the Direction of Rationalizing and Accounting Evidence (the Resolution of the Council of Ministers no. 753/1957), the Direction of the Evidence and Accounting Reports (Decree no. 840/1964), the Direction of Methodology and the Guiding of the Accounting (Decree no. 784/1969), the Direction of Norming, Methodology and the Guiding of the Accounting (Decree no. 123/1973). It must be mentioned that the term used between 1947 and 1970 was that of "norming of the accounting evidence", not "normalization of the accounting". Through the Direction of Norming of Accounting Evidence were assured not only the working out of methodological norms for running out the accounting but also the guiding and the control of the way those norms were applied in the socialist units. In working out those norms and passing them forward, this organism co-worked with: State Committee of Planning, Central Direction of Statistics, National Bank as well as the directions of accounting within the economic ministries.

The roles of the Direction of Norming of Accounting Evidence which were, in fact, the issue of normalizing, were the following (the Resolution of the Council of Ministers no. 1636/1984, art.5):

- $\quad$ working out the charts of accounts for norming the accounting;

- $\quad$ working out the instructions for proper and uniform application of the charts of accounts; 
- $\quad$ noticing the proposals of the economic ministries regarding: modification of charts of accounts, introduction of new accounts within the on-going plans, applying the instructions referring to analytical accounts made by economic ministries;

- working out the integrated patterns of periodical accounting situations (balance sheet, accounts of losses and profits, accounting reports etc);

- working out the proposals of standardizing the forms of accounting (registers, sheets etc)

- $\quad$ noticing the accounting interpretations of laws and regulations and working out the instructions for their application from the point of view of accounting;

- $\quad$ studying and proposing measures of any type that should be taken by the economic ministries for organizing and norming the accounting.

Later, as it was natural, taking into account the evolutions recorded in economy, the new problems raised concerning the accounting, the roles of the Ministry of Finances practiced through the Direction of Methodology and Guiding of the Accounting expanded, including also:

- $\quad$ working out integrated norms and rules regarding the organizing and running out the accounting;

- $\quad$ working out methodological norms for planning, the accounting of expenses and the calculation of costs within different fields of activity, together with State Committee of Planning, Central Direction of Statistics and the other central organisms;

- working out the catalogue, the form of presentation and the circuit of common and general financial-accounting documents, specific to different fields and subfields of activity;

- establishing the forms of accounting and the methods of analytical accounting of material values which are used in economy;

- working out the patterns of documents and programmes for financialaccounting works so they can be accomplished using technical methods of calculation.

- $\quad$ centralizing and analyzing the accounting reports of the central organisms;

- $\quad$ organizing the activity and guidance of the accounting expertise bodies.

At the level of economic ministries, Directions of Accounting were organized which, beside adapting the methodological norms elaborate by the Ministry of Finances to the specific of the field or the subordinate units, were also meant to provide:

- modification of the chart of accounts applicable to the units subordinate to those specific ministries (introduction of new accounts / subaccounts), with the approval of Ministry of Finances;

- dividing the chart of accounts into analytical accounts, corresponding to the specific of the subordinate units and, in the same time, guidance for applying the chart of accounts and other elaborate norms regarding the organization and running out of the accounting;

- guidance and professional control of the financial activity of the subordinate units, of the way of functioning of the accounting;

- verifying, analyzing, approving and centralizing the accounting registers, their balance sheets; working out the financial planning works.

We can appreciate that another two organisms were also involved in the activity of normalizing the accounting, namely: The Commission for Organizing and Rationalizing the Primary Accounting, founded in 1950 by the Resolution of the Council of Ministers no. 43/1950, which had as purpose organizing, rationalizing, guiding and controlling the primary accounting in enterprises, economic organizations and state institutions; The Governmental Commission for Rationalizing the System of 
Accounting in the Socialist Units, founded with the purpose of applying the Programme Concerning the Rationalizing the Accounting System in the Socialist Units (approved by the Resolution of the Council of Ministers no. 1719/1971), at the level of ministries, central organisms and local councils functioning subcommissions of improving the informational system.

It must also be noticed the fact that, within this period, the profession of the accountant was not involved, in any way, in the process of normalizing the accounting. As long as, after the establishing of the communist regime, the free initiative was replaced by the guided economy, the existence of an organism of the profession of accountant, a profession known as liberal, was becoming almost impossible (CECCAR, 2006, pp. 75). So that, during the four decades of socialist economy, the Body of Licensed Accountants and Expert Accountants in Romania did not really exist, being eliminated in March 1951, by the Decree no. 40, March $10^{\text {th }}$, given by the Great National Assembly, following the Resolution of the Council of Ministers no. 201 from 1951, March $8^{\text {th }}$.

\section{The institution of accounting normalization in the post-revolutionary stage}

Since 1989, Romania has witnessed many changes, and the transition from centrally planned economy to a market economy, in which transactions are determined by supply and demand, not government intervention, called for deeper economic reforms. These reforms required appropriate adjustments in the organization and management of accounting of the economic operators, therefore, a reform of the accounting system in all its elements, such as objectives, fundamental accounting principles, rules and methods of basic accounting, detailed accounting procedures, was also expected.

Regarding the institution of accounting normalization in our country, there were no significant changes immediately after 1989. The normalization of accounting has remained the exclusive prerogative of the State, all being done through the Ministry of Economy and Finance, the General Direction of Accounting established by the Government Decision no. 328/1991. Among the main roles of this Ministry, one is identified as being referred to the normalizing of accounting, namely "drawing general, legal and institutional framework on accounting". The name of this Ministry changed after 1991, becoming the Ministry of Finance (Government Decision - GD no. 788/1992), after that, the Ministry of Public Finances (GD no. 18/2001), then ,The Ministry of Economy and Finances (GD no. 386/2007) and, since 2009, its name has been The Ministry of Public Finances (GD no. 34/2009). In its organizational framework is found only one direction with responsibilities in the development of accounting regulations for both the private and public sectors, or two such directions, one for the private sector and the other for the public sector.

At present, the normalization of accounting in Romania is being administered by the Ministry of Public Finance through the Direction of Legislation and Accounting Regulations (according to GD no. 34/2009), assisted by the Accounting and Financial Reporting Council. In Annex no. 2, GD no. 34/2009, the Accounting and Financial Reporting Council is within the operating activities which function by the Ministry of Public Finance.

The duties of this ministry when it comes to the normalization of accounting, are set by the Accounting Law no. 82/1991 (Article 4), which states that "The Ministry of Public Finances shall work out and put forward norms and regulations concerning the accounting, chart of accounts, financial statements models, common registers and forms regarding the financial and accounting activities, methodological norms for 
establishing their use." It will also "work out and put forward norms concerning the single-entry accounting" with "consulting the specialized professional bodies."

The Accounting Law no. 82/1991 (Article 4, al.3) says that organisms that regulate and supervise certain specific sectors (banking, insurance, private pensions sector and the sector of capital markets), have also an important role in the normalization of accounting. The accounting norms and regulations applicable to entities within these sectors are developed by the National Bank of Romania (Banca Naţională a României - BNR), the National Securities Commission (Comisia Naţională a Valorilor Mobiliare - CNVM), the Insurance Supervisory Commission (Comisia de Supraveghere a Asigurărilor - CSA), the Supervisory Commission of Private Pensions System (Comisia de Supraveghere a Sistemului de Pensii Private - CSSPP), all this approved by the Ministry of Public Finances. It should be noticed that, according to the Government Emergency Ordinance no. 93/2012, the BNR, CSA and CSSPP were abolished, the roles and prerogatives of these bodies being taken over by the Financial Supervisory Authority (Autoritatea de Supraveghere Financiară - ASF), the newly established body. ASF exercises the powers of licensing, regulation, supervision and control over the bodies of the three sectors activity: the Sector of Financial Instruments and Investments, the Sector of insurance-reinsurance, and the Sector of Private Pensions System.

Considering the above, the mission of the Ministry of Public Finance concerning the normalization of accounting, including its relation to other bodies with regulatory powers in accounting field, can be synthetically rendered as in Figure 1.

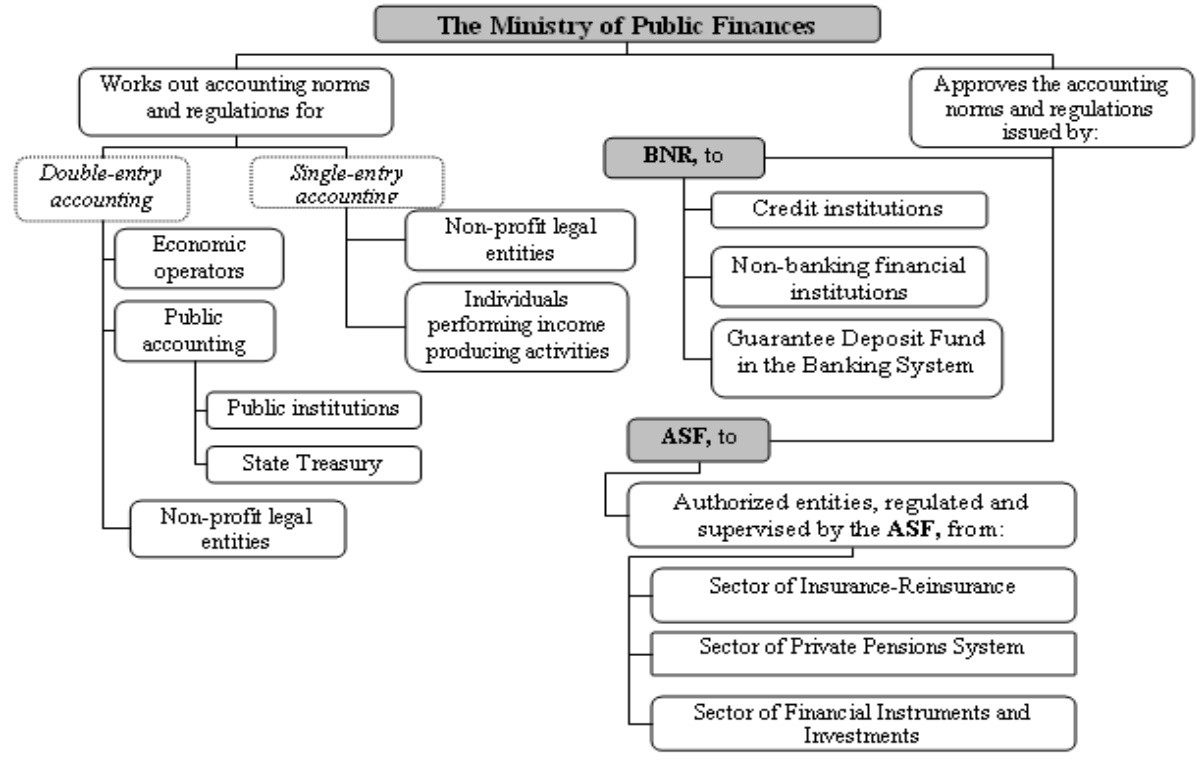

Figure 1 Bodies with regulatory powers in accounting in Romania

Source: Adapted from Rotilă, A. (2011), Reglementări şi practici contabile specifice, Alma Mater Publishing, Bacău, p. 30

As it is known, since 1994, Romanian accounting has undergone a profound reform, which meant, from the point of view of a regulatory and practical plan, implementing a "new accounting system", a dualist system, inspired from the West European continental system. Through this system was triggered the alignment of Romanian accounting norms to EU accounting norms, using as a model the French experience. The application of this "new accounting system" has been prepared since 1992, 
meaning that the Ministry of Economy and Finance, through the Direction of Accounting, prepared a draft on The Regulation on the Application of the Accounting Law, which was experienced in the first trimester of 1993 in a number of 70 trading companies and autonomous regies in within various industries. The experiment was approved by Government Decision no. 575/22 September 1992. Once the approval of experimenting the Project on accounting rules and methodologies was given, by GD no. 575/22 September 1992,it was ordered the founding of the Consultative College of Accounting (Colegiului Consultativ al Contabilităţii), under The Ministry of Economy and Finances, and the assurance, by these two bodies, of specialized staff trained following a certain schedule. The Consultative College of Accounting, as an organism of consultation and analysis in the process of working out the norms and regulations of accounting, and due to its composition, was meant to let be actively involved, in the normalizing of accounting, all those interested in the accounting information. The composition of the Council, approved by the Government Decision together with the approval of the Regulation of organization and functioning of the Consultative College of Accounting, is presented in Figure 2. Initially approved by Government Decision no 575/1992, the Regulation was replaced in 2002 with new Regulation, approved by Government Decision no 1449 of December 12, 2002, and then were also reviewed the attributions, organization, operation and the financing of the College.

\begin{tabular}{|c|c|}
\hline According to GD no.575/1992 & According to GD no. $1449 / 2002$ \\
\hline $\begin{array}{l}\checkmark \text { a president, secretary of state in the } \\
\text { Ministry of Economy and Finances; }\end{array}$ & $\begin{array}{l}\checkmark \text { a president, secretary of state in the Ministry of } \\
\text { Public Finances, a Coordinator of the Direction of } \\
\text { Accounting Regulations; }\end{array}$ \\
\hline $\begin{array}{l}\text { five vice presidents, academic } \\
\text { representatives, Romanian Court of Accounts } \\
\text { representatives, representatives of the } \\
\text { Romanian General Association of Economists, } \\
\text { representatives of Body of Expert and } \\
\text { Licensed Accountants of Romania } \\
\text { (CECCAR); }\end{array}$ & $\begin{array}{l}\text { five vice presidents, representatives of the } \\
\text { Chamber of Financial Auditors of Romania, the Body } \\
\text { of Expert and Licensed Accountants of Romania the } \\
\text { Romanian Chamber of Tax Consultants, financial and } \\
\text { banking institutions and economic academia; }\end{array}$ \\
\hline a secretary; & $\checkmark$ a general secretary; \\
\hline $\begin{array}{l}50 \text { me mbers representing: } \\
\text { Ministry of Economy and Finances (8), } \\
\text { CECCAR (5), financial directors and chief } \\
\text { accountants (10), the Romanian Court of } \\
\text { Accounts, the State Property Fund, Private } \\
\text { Property Fund, Commodity Exchange, } \\
\text { National Agency for Privatisation and SMEs } \\
\text { Development, Chamber of Commerce and } \\
\text { Industry, Trade Register, Employers' } \\
\text { Associations, Academic ( } 7 \text { ), Ministries ( } 9 \text { - } \\
\text { one representative of each ministry), the } \\
\text { National Bank, the National Commission of } \\
\text { Informatics, the National Commission of } \\
\text { Statistics. }\end{array}$ & $\begin{array}{l}\text { 15 me mbers, representatives of: } \\
\text { CNVM, Bucharest Stock Exchange, BNR, CSA, } \\
\text { Chamber of Commerce and Industry of Romania and } \\
\text { Bucharest, Court of Accounts, Ministry of Justice, } \\
\text { National Institute of Statistics, specialized } \\
\text { departments of economic higher education institutions } \\
\text { and specialized departments of the Ministry of Public } \\
\text { Finances. }\end{array}$ \\
\hline
\end{tabular}

\section{Figure 2 The composition of the Consultative College of Accounting}

Although the attributions of the Consultative College of Accounting would have allowed it a strong involvement in the process of normalizing of accounting, in the period that followed, in reality, the role of this organism was limited; basically, the Ministry of Economy and Finances through the Direction of Accounting Regulations held full power in terms of accounting normalization.

To develop the institutional framework of accounting and the accounting profession in 2005, it is established, through the reorganization of the Consultative College of Accounting (HG nr. 401/2005), the Accounting and Financial Reporting Council (Consiliul Contabilităţii şi Raportărilor Financiare - CCRF), an independent 
oversight organism which ensures the convergence of national regulations and practices in the field of accounting and financial auditing to the regulations applicable in the European Union.

The work of this organism aims to increase the confidence of users of information in the financial reporting and corporate governance. In order to develop the national accounting standards, the Regulation of Organization and Functioning of CCRF (Approved by Government Decision no. 401/2005, modified and completed by GD no. 141/2006) stipulates the organization of two distinct departments within the Council (Article 6, par. 4):

- The Department for the development of the national accounting standards for the private sector;

- The Department for the development of the national accounting standards for the public sector.

Immediately after the founding, within the CCRF were established a number of committees and working groups.

CCRF is led by a Superior Board composed of representatives of key institutions with regulatory powers in accounting and financial audit, involved in the implementation of the Country Action Plan in order to improve the financial reporting in Romania, as well as representatives of the business and academic media. The composition of the Superior Board, referred to in Article 4, al. (2) of the Regulation of Organization and Functioning of the Accounting and Financial Reporting Council approved by the Government Decision no. 401/2005, modified and completed by GD no. 141/2006, is presented in Figure 3.

\begin{tabular}{l}
\hline \multicolumn{1}{|c|}{ According to GD no. 575/1092 } \\
\hline \hline$\checkmark$ The Minister of Public Finances who also serves as president during the implementation of \\
the Country Action Plan; \\
\hline \hline$\checkmark$ The Secretary of State in the Ministry of Public Finances, who coordinates the department \\
having responsibilities in development of accounting rules for private sector, as vice president \\
and as a replacement of the President; \\
\hline \hline$\checkmark$ The Secretary of State in the Ministry of Public Finances, who coordinates the department \\
responsible for public sector accounting regulations development, as vice president; \\
\hline \hline$\checkmark$ one representative designated by each of the regulatory and supervisor organisms: BNR, \\
CNVM, CSA; \\
\hline \hline$\checkmark$ one representative nominated by each of the professional accounting organisms, CAFR and \\
CECCAR; \\
\hline \hline$\checkmark$ a representative of the Minister of Justice; \\
\hline \hline$\checkmark$ a representative of academic media, appointed by the Minister of Education and Research; \\
\hline \hline$\checkmark$ a representative of business, appointed by the employers' confederations, nationally \\
representative and internationally recognized.
\end{tabular}

\section{Figure 3 The Composition of the Superior Board of CCRF}

The operative organism of the Council is the Executive Committee, composed of five technical directors with great experience in accounting and financial auditing, and management financial - accounting. Besides these, within the Executive Committee there is a technical secretariat consisting of three persons (employees of the Ministry of Public Finances).

Through these structures, correlated to the basic objectives of the Council, is accomplished the activity of monitoring and supervision in accounting and financial audit field, carried out to improve the quality of financial reporting.

It should be taken into account that, at this stage, the accounting profession has some involvement in the normalization of accounting. The professional organisms are involved in the activities led by the CCRF, through the active participation of their 
representatives in both the Superior Board Meetings of CCRF and also in the Working Commissions of the CCRF, where designated specialists of these bodies are required to participate in debates and consultations on developing / improving legislation on the field.

\section{Conclusions}

The normalization of accounting in Romania, a normalization of public type, started in the first year of the planned management of the national economy (1949), as the consequence of the need to ensure the control on the integrity of socialist property and the pursuit of the State Plan.

The December 1989 events created the premises of the economic reform and, consequently, of the reorganization of the Romanian accounting system, also marking the normalization of accounting. In fact, it is achieved the passing from the normalization of accounting of a soviet specific accounting system in which the normalizing was solely the prerogative of the state, achieved by the Ministry of Finance, Direction of Norming of Accounting Evidence, to another model of normalization, specific to an accounting system of Western European inspiration. In this accounting system, the normalization is also the prerogative of the state, being done by the Ministry of Public Finances, but under this ministry was also created a joint organism of normalizing of accounting, which brings together a wide range of "actors" interested in accounting information, namely the Consultative College of Accounting, later become, through reorganization, the Accounting and Financial Reporting Council. Besides the Ministry of Public Finances which is the institution of the normalization of accounting in Romania, there are also other organisms that regulate and supervise certain specific sectors (banking, insurance, private pensions and capital markets).

The normalization of Romanian accounting tends to work out in the mixed type. Thus, the mixed type normalization is becoming a reality sooner or later, depending on the extent to which other parties interested, especially the professional accountancy organisms, will be permitted to become involved in the process of normalization. These parties are already represented in the organism created for this purpose, the Accounting and Financial Reporting Council.

\section{References}

Camera Auditorilor Financiari din România (2012), Raport 2012, available at http://www.cafr.ro/uploads/Raport\%202012\%20RO-1617.pdf.

CECCAR (2006), Album 85 de ani de la înfiinţarea Corpului Experţilor Contabili şi Contabililor Autorizaţi din România, Bucharest, Editura CECCAR.

CECCAR (2012), Raport Anual 2012, available at http://ceccar.ro/ro/wpcontent/uploads/2012/06/Raport-anual-2012-romana.pdf.

Decizia Consiliului de Miniştri nr. 1636 din 10 decembrie 1948, referitoare la introducerea obligatorie a contabilităţii normate.

Decretul Consiliului de Stat nr. 784/1969 privind organizarea şi funcţionarea Ministerului Finanţelor, with subsequent amendments by Decretul $\mathrm{nr}$. 123/1973.

Feleagă, N., Ionaşcu, I. (1998), Tratat de contabilitate financiară, vol. I, Bucharest, Editura Economică.

Hotărârea Guvernului nr. 575/1992 cu privire la cu privire la experimentarea noului sistem de contabilitate şi constituirea Colegiului Consultativ al Contabilităţii. 
Hotărârea Guvernului nr. 1449/2002 privind aprobarea Regulamentului de organizare şi funcţionare a Colegiului Consultativ al Contabilităţii.

Hotărârea Guvernului nr. 401/2005 privind înfiinţarea Consiliului Contabilităţii şi Raportărilor Financiare prin reorganizarea Colegiului Consultativ al Contabilităţii, with subsequent amendments by Hotărârea Guvernului nr. 141/2006.

Legea contabilităţii $n r$. 82/1991, republished, with subsequent amendments.

Ordonanţa de Urgenţă a Guvernului (OUG) nr. 93/2012 privind înfiinţarea, organizarea şi funcţionarea Autorităţii de Supraveghere Financiară .

Ristea, M., Dumitru, C. G., Ioanăş, C., Irimescu, A. (2009), Contabilitatea societăţilor comerciale, vol. I, Bucharest, Editura Universitară.

Rotilă, A. (2011), Reglementări şi practici contabile specifice, Bacău, Alma Mater Publishing House. 